\title{
PEMANFAATAN MODAL SOSIAL DALAM PENGEMBANGAN SEKTOR PERDAGANGAN PADA USAHA MIKRO KECIL DAN MENENGAH (Studi di Tapanuli Utara)
}

\author{
Harisan Boni Firmando \\ IAKN Tarutung \\ boni.harisan@iakntarutung.ac.id
}

\begin{abstract}
Writing a journal entitled "Utilization of Social Capital in the Development of the Trade Sector in Micro, Small and Medium Enterprises (Study in North Tapanuli)" begins with a new economic paradigm that sees multidimensional development reflected in various social perspectives. The trade sector is a solution for the implementation of development, especially from the joints of the national economy. The presence of micro, small and medium enterprises in the trade sector can maintain economic stability, especially in strengthening the structure of the national economy. The method used in this research is descriptive method with a qualitative approach. Data were collected by observation and interviews. The unit of analysis and informants in this study were traders and customers of micro, small and medium enterprises in North Tapanuli. The data were interpreted using field notes. The results show that the use of social capital in micro, small and medium enterprises makes them strong, independent and has high competitiveness, where all business actors play a major role in economic activities, from process, production, distribution to consumption.

Keywords:Economic Growth, Social Capital, Trade Sector.
\end{abstract}

\begin{abstract}
Abstrak
Penulisan jurnal yang berjudul "Pemanfaatan Modal Sosial dalam Pengembangan Sektor Perdagangan Pada Usaha Mikro Kecil dan Menengah (Studi di Tapanuli Utara)" dimulai dengan paradigmabaru ekonomimelihat pembangunan secara multidimensi yang tercermin dalam berbagai perspektif sosial. Sektor perdagangan menjadi solusi bagi terlaksananya pembangunan terutama dari sendi perekonomian nasional.Kehadiran usaha mikro, kecil dan menengah dalam sektor perdagangan dapat menjaga stabilitas perekonomian terutama dalam memperkuat struktur perekonomian nasional.Metode yang digunakan dalam penelitian ini adalah metode deskriptif dengan pendekatan kualitatif. Data dikumpulkan dengan observasi dan wawancara. Unit analisis dan informan dalam penelitian ini adalah pedagang dan pelanggan usaha mikro kecil dan menengah di Tapanuli Utara. Data ditafsirkan menggunakan catatan lapangan.Hasil penelitian menunjukkan bahwa pemanfaatan modal sosial padausaha mikro, kecil dan menengah menjadikan usaha tersebut mandiri dan tangguh serta memiliki daya saing yang tinggi, dimana semua pelaku usaha berperan utama dalam kegiatan ekonomi, mulai dari proses, produksi, distribusi hinggadikonsumsi.

Kata kunci:Pertumbuhan Ekonomi,Modal Sosial, Sektor Perdagangan.
\end{abstract}




\section{Pendahuluan}

Keberhasilan suatu negara dapat dilihat dari tingkat pertumbuhan ekonomi di negara tersebut.Pertumbuhan ekonomi adalah salah satu indikator penting yang dapat digunakan untuk menganalisis pembangunan ekonomi yang terjadi pada suatu negara. Paradigmabaru dalam ekonomi melihat pembangunan secara multidimensi yang tercermin dalam berbagai perspektifsosial ${ }^{1}$.Negara-negara dengan institusi yang lebih baik akan mampumengalokasikan sumberdaya secara lebih efisien, sehingga perekonomian bisa bekerja lebih baik ${ }^{2}$. Institusi tersebut sebagai aturanaturan yang diciptakan untuk mengatur berbagai interaksi manusiayang juga me ncakup aturan informal yang salah satunya adalah modal sosial ${ }^{3}$. Modal sosial saat ini dipandang sebagai resep utama dalam perkembangan pembangunan ekonomi ${ }^{4}$.

Modal sosial menunjuk pada segi-segi organisasi sosial, seperti kepercayaan, norma-norma, dan jaringan-jaringan sosial yang dapat memfasilitasi tindakan kolektif. Modal sosial ditekankan pada kebersamaan masyarakat untuk memperbaiki kualitas hidup bersama dan melakukan perubahan yang lebih baik serta penyesuaian secara terus menerus. Kemampuan masyarakat untuk dapat saling bekerjasama tidak dapat terlepas dari adanya peran modal sosial yang mereka miliki. Inti modal sosial terletak pada bagaimana kemampuan masyarakat dalam suatu entitas atau kelompok untuk bekerja sama membangun suatu jaringan untuk mencapai tujuan bersama. Kerjasama tersebut diwarnai oleh suatu pola interrelasi yang timbal balik dan saling menguntungkan (re-siprocity), dan dibangun atas kepercayaan (trust) yang ditopang oleh norma-norma dan nilai-nilai sosial yang positif dan kuat.

Modal sosial merupakan sumberdaya berupa jaringan kerja yang memiliki pengetahuan tentang nilai, norma, dan struktur sosial atau kelembagaan yang memiliki semangat kerjasama, kejujuran/kepercayaan, berbuat kebaikan, sebagai pengetahuan bersikap, bertindak, dan berperilaku yang akan memberikan implikasi positif kepada produktivitas. Sejalan dengan perkembangan dunia bisnis yang demikian pesat, ketergantungan pengusaha terhadap pihak-pihak di luar usaha semakin kuat. Para pengusaha mulai berpikir untuk saling melengkapi atau saling mendukung kegiatan satu dengan yang lainnya melalui kerjasama yang saling menguntungkan. 
109 AT-TAWASSUTH: Jurnal Ekonomi Islam, Volume VI No. 1

Januari - Juni 2021: 107 - 131

Modal sosial berperan dalam menjalin kerjasama antara masyarakat dengan lembaga-lembaga keuangan yang diharapkan untuk membantu pengembangan usaha masyarakat. Pendekatan modal sosial ini merupakan alternatif dari strategi pengembangan ekonomi masyarakat golongan ekonomi lemah yang lazimnya ditunjang dana yang berasal dari bantuan proyek yang dikelola pemerintah.

Pada umumnya usaha mikro kecil dan menengah memiliki karakteristik pada lemahnya jaringan antar kelembagaan yang ada, baik secara horizontal maupun secara vertical. Hal ini disebabkan karena mereka tidak memiliki persyaratan sosial yangcukup, misalnya lemahnya pendidikan, pengetahuan, ketrampilan dan kemampuan berkomunikasi yang baik. Modal sosial merupakan salah satu modal dasar yang kurang diperhatikan selama ini. Dengan dasar ini, maka upaya pemanfaatan modal sosial sebagai salah satu aspek penting dalam meningkatkan efektivitas kerja pelaku usaha harus semakin ditingkatkan.

Pengembangan usaha mikro, kecil dan menengah sangat strategis dalam mengantisipasi perekonomian kedepan terutama dalam memperkuat struktur perekonomian nasional. Krisis perekonomian nasionalyang terjadi saat ini sangat mempengaruhi stabilitas nasional, ekonomi dan politikyang berdampak pada berbagai kegiatan usaha besar yang semakinterpuruk, sementara usaha mikro, kecil dan menengah serta koperasi relatif masih dapat mempertahankankegiatan usahanya. Tujuan umum yang ingin dicapai adalah terwujudnyausaha mikro, kecil dan menengah yang mandiri dan tangguh serta memiliki daya yang saing tinggi dimana semua pelaku usaha berperan utama dalam kegiatan ekonomi, mulai dari proses, produksi, distribusi hingga dikonsumsi.

Fokus utama dalam tulisan ini mendeskripsikan pemanfaatan modal sosial dalam pengembangan sektor perdagangan pada usaha mikro kecil dan menengah. Adanya indikasi kuat bahwa saat ini modal sosial belum begitu dimanfaatkan dalam pengembangan sektor perdagangan yang berperan penting dalam keberlanjutan usaha. Pentingnya peranan kerjasama dalam modal sosial dapat memaksimalkan 
kesejahteraan sosial. Pengelompokan sumber modal sosial disesuaikan dengan pendekatan yang digunakan dalam pengukuran modal sosial tersebut dan secara garis besar dibedakan atas tiga kelompok utama yaitu Trust (rasa percaya), Share value (Norma) dan Network (Jaringan Kerja) .

Menyikapi sektor perdagangan ini perlu diketengahkan pertanyaan mayor: bagaimana pemanfaatan modal sosial dalam pengembangan sektor perdagangan pada usaha mikro kecil dan menengah? Adapun pertanyaan minornya: bagaimana proses pengembangan sektor perdagangan oleh pelaku usahakecil mikro dan menengah? Apa

saja bentuk-bentuk modal sosial yang dilakukan pelaku usaha mikro kecil dan menengah?

\section{Kajian Teori}

\section{Teori Modal Sosial}

Modal sosial (social capital) dapat didefinisikan sebagai kemampuan masyarakat untuk bekerja bersama, demi mencapai tujuan-tujuan bersama, di dalam berbagai kelompok. Fukuyama mendefinisikan, modal sosial sebagai serangkaian nilai-nilai atau norma-norma informal yang dimiliki bersama diantara para anggota suatu kelompok yang memungkinkan terjalinnya kerjasama di antara mereka. Singkatnya kehidupan ekonomi tidak bisa dipisahkan dari kebudayaan, dimana kebudayaan membentuk seluruh aspek manusia, termasuk perilaku ekonomi dengan sejumlah cara yang kritis ${ }^{6}$.

Coleman memperkenalkan modal sosial sebagai sarana konseptual untuk memahami orientasi teoritis tindakan sosial dengan mengaitkan komponen-komponen dari perspektif sosiologi dan ekonomi. Coleman berpendapat bahwa pengertian modal sosial ditentukan oleh fungsinya. Sekalipun sebenarnya terdapat banyak fungsi modal sosial tetapi ia mengatakan bahwa pada dasarnya semuanya memiliki dua unsur yang sama, yakni: pertama, (1) modal sosial mencakup sejumlah aspek dari struktur sosial, dan (2) modal sosial memberi kemudahan bagi orang untuk melakukan sesuatu dalam kerangka struktur sosial tersebut. Ia memberi penekanan terhadap dua aspek dari struktur sosial yang sangat pentingdalam memudahkan tercipta dan berkembangnya modal sosial dalam berbagai bentuk. Pertama, aspek dari struktur sosial yang 
menciptakan dorongan dalam sebuah jaringan sosial yang membuat setiap orang saling berhubungan sedemikian rupa sehingga kewajiban-kewajiban maupun sanksi-sanksi dapat dikenakan kepada setiap orang yang menjadi anggota jaringan itu. Kedua, adanya organisasi sosial yang dapat digunakanuntuk mencapai tujuan bersama.

Coleman mengidentifikasi tiga unsur utama yangmerupakan pilar modal sosial. Pertama, kewajiban dan harapan yangtimbul dari rasa kepercayaan dalam lingkungan sosial. Ia mengambilcontoh sistem arisan yang populer dalam masyarakat di banyak negaraAsia Tenggara, termasuk Indonesia. Sistem arisan yang dilakukan olehsekelompok orang yang memiliki hubungan pertemanan, tetangga ataukekerabatan merupakan sebuah contoh yang jelas tentang bagaimanapentingnya arti kepercayaan. Pilar kedua modal sosial menurut Colemanadalah pentingnya arus informasi yang lancar di dalam struktur sosialuntuk mendorong berkembangnya kegiatan dalam masyarakat. Arusinformasi yang tidak lancar cenderung menyebabkan orang menjadi tidaktahu atau ragu-ragu sehingga tidak berani melakukan sesuatu. Pilar ketigaadalah norma-norma yang harus ditaati dengan sanksi yang jelas danefektif. Tanpa adanya seperangkat norma yang disepakati dan dipatuhi olehsegenap anggota masyarakat maka yang muncul adalah keadaan anomiedimana setiap orang cenderung berbuat menurut kemauan sendiri tanpamerasa ada ikatan dengan orang lain. Juga tidak ada mekanisme untukmenjatuhkan sanksi karena tidak ada norma yang disepakati bersamaberkaitan dengan sanksi tersebut. Dengan demikian pengembangan modalsosial pada dasarnya ditujukan untuk membangun ketiga pilar yangdimaksudkan Coleman itu? .

Modal sosial mirip bentuk-bentuk modal lainnya, dalam arti ia juga bersifat produktif. Modal sosial dapat dijelaskan sebagai produk relasi manusia satu sama lain, khususnya relasi yang intim dan konsisten. Modal sosial menunjuk pada jaringan, norma dan kepercayaan yang berpotensi pada produktivitas masyarakat. Namun demikian, modal sosial berbeda dengan modal finansial, karena modal sosial bersifat kumulatif dan bertambah dengan sendirinya. Karenanya, modal sosial tidak akan habis jika dipergunakan, melainkan semakin meningkat. Rusaknya modal sosial lebih sering disebabkan bukan karena dipakai, melainkan karena ia tidak dipergunakan. Berbeda 
dengan modal manusia, modal sosial juga menunjuk pada kemampuan orang untuk berasosiasi dengan orang lain. Bersandar pada norma-norma dan nilai-nilai bersama, asosiasi antar manusia tersebut menghasilkan kepercayaan yang pada gilirannya memiliki nilai ekonomi yang besar dan terukur ${ }^{8}$.

\section{Metode Penelitian}

Metode yang digunakan dalam penelitian ini adalah metode penelitian deskriptif dengan menggunakan pendekatan kualitatif. Sebagaimana yang dikemukakan oleh Taylor dan Bogman (1984) dalam Bagong Suyanto dan Sutinah ${ }^{9}$ bahwa penelitian kualitatif dapat diartikan sebagai penelitian yang menghasilkan data deskriptif mengenai kata-kata lisan maupun tertulis, dan tingkah laku yang dapat diamati dari orang-orang yang diteliti. Penelitian kualitatif juga dapat diartikan sebagai pendekatanyang menghasilkan data, tulisan, dan tingkah laku yang di dapat dari apa yang diamati ${ }^{10}$. Metode penelitian deskriptif merupakan jenis penelitian yang bertujuan untuk memberikan gambaran mengenai sesuatu masalah ${ }^{11}$. Dengan demikian penelitian ini menggambarkan fakta-fakta tentang bagaimana pemanfaatan modal sosial yang dilakukan oleh para pelakuusaha mikro, kecil dan menegah di Tapanuli Utara agar dapat mengembangkan usahanya.

\section{Hasil dan Pembahasan}

\section{Pengaruh Sektor Perdagangan Dalam Pertumbuhan Ekonomi}

Pertumbuhan ekonomi (Economic Growth) adalah perkembangan kegiatan dalam perekonomian yang menyebabkan barang dan jasa yang diproduksikan dalam masyarakat bertambah dan kemakmuran masyarakat meningkat. Masalah pertumbuhan ekonomi dapat dipandang sebagai masalah makro ekonomi dalam jangka panjang.Untuk meningkatkan pembangunan nasional, maka harus didukung dengan pembangunan daerah yang dilaksanakan secara tepat. Laju pertumbuhan ekonomi daerah biasanya digunakan untuk menilai seberapa jauh keberhasilan pembangunan daerah dalam periode waktu tertentu.Pembangunan ekonomi daerah adalah suatu proses dimana pemerintah daerah dan masyarakatnya mengelola sumber-sumber daya yang ada dan membentuk suatu pola kemitraan antara pemerintah daerah dan swasta untuk menciptakan lapangan kerja baru dan merangsang perkembangan kegiatan ekonomi dalam wilayah tersebut ${ }^{12}$. 
Pertumbuhan ekonomi secara klasik dipengaruhi oleh dua faktor utama yakni pertumbuhan output total dan pertumbuhan penduduk. Pertumbuhan ekonomi sangat dipengaruhi oleh produktivitas sektor-sektor dalam menggunakan faktor-faktor produksinya. Kenyataan seperti ini menyisakan pertanyaan, mengapa pertumbuhan ekonomi yang terus meningkat dari tahun ke tahun tidak diikuti oleh penurunan angka pengangguran, atau pengangguran justru meningkat setiap tahunnya. Padahal secara teori pertumbuhan ekonomi menurut pandangan para ekonom Klasik yang antara lain Adam Smith, David Ricardo, Thomas Robert Malthus dan John Stuart Mill, maupun ekonom Neo-Klasik antara lain Robert Solow dan Trevor Swan, pada dasarnya ada empat faktor yang mempengaruhi pertumbuhan ekonomi, yaitu (a) jumlah penduduk, (b) jumlah stok barang modal, (c) luas tanah dan kekayaan alam, dan (d) tingkat teknologi yang digunakan ${ }^{13}$.

Salah satu unsur yang penting dan menjadi faktor positif dalam mendorong pertumbuhan ekonomi adalah pertumbuhan penduduk dan tenaga kerja. Jumlah tenaga kerja yang lebih besar berarti akan menambah jumlah tenaga produktif, sedangkan pertumbuhan penduduk yang lebih besar akan meningkatkan luasnya pasar domestik. Namun kenyataan yang terjadi pertumbuhan penduduk yang sangat cepat juga akan memberikan efek negatif terhadap perkembangan ekonomi, sehingga diperlukan sistem perekonomian yang mampu untuk menyerap dan secara produktif mempekerjakan tambahan tenaga tersebut ${ }^{14}$.

Teori pertumbuhan baru memberikan kerangka teoritis untuk menganalisis pertumbuhan yang bersifat endogen. Pertumbuhan ekonomi merupakan hasil dari dalam sistem ekonomi. Kemajuan teknologi merupakan hal yang endogen, pertumbuhan merupakan bagian dari keputusan pelaku-pelaku ekonomi untuk berinvestasi dalam pengetahuan. Peran modal lebih besar dari hanya sekedar bagian dari pendapatan apabila modal yang tumbuh bukan hanya modal fisik saja tapi menyangkut modal sosial.

Demi memajukan tingkat kesejahteraan penduduk, pemerintah mencoba membangun bangsanya sebagai bangsa yang mandiri, namun ternyata sulit untuk terus bertahan di tengah derasnya arus globalisasi yang terus berkembang dengan cepat. 
Dalam kondisi seperti ini, pemerintah akhirnya terpaksa harus mengikuti arus tersebut, yaitu mencoba memperbaiki diri diantaranya dengan melakukan pengembangan sektor perdagangan demi terlaksananya pembangunan nasional terutama dari sendi perekonomian nasional.

Pada prinsipnya, perdagangan adalahsetiap kegiatan atau serangkaian kegiatandalam rangka penjualan dan atau pembelianbarang, termasuk penawaran untuk menjualdan kegiatan lain yang berkenaan denganpemindahtanganan barang dengan memperolehimbalan. Aset dan perilaku bisnis jugadipengaruhi oleh keberadaan lembaga pasarformal sepertihukum dan aturan perdagangan, jasa penyidikan, asosiasi perdagangan dansistem informasi. Asetyang dimiliki bersama-sama dengan faktorinfrastruktur transportasi, komunikasi, dan jasapergudangan, secara langsung membentukperilaku pedagang dalam kegiatan bisnisnya.

Jenis barang yang diperdagangkan pada daerah Tapanuli Utara secara umum adalah jenis barang yang diperdagangkan di lokasi pasar yang merupakan kebutuhan masyarakat umum. Barang yang diperdagangkan berupa barang-barang kebutuhan pokok yakni hasil-hasil pertanian, seperti beras, sayur-sayuran dan buah-buahan, hasil perikanan. Barang-barang peralatan rumah tangga juga turut di perdagangkan baik produk hasil pabrikan maupun produk industri rumah tangga. Produk industri rumah tangga yang semakin dikembangkan yaitu kerajinan tenun tradisional serta makanan dan minuman olahan seperti kacang dan kopi yang beragam jenis.

Sektor perdagangan informal masih secara umum ditemui di Tapanuli Utara, yang terdiri dari unit usaha berskala kecil. Tujuan utama barang dan jasa diproduksi dan didistribusikan untuk menciptakan kesempatan kerja dan kesempatan memperoleh pendapatan bagi pelakunya. Berbagai kendala sering dihadappi sektor perdagangan informal seperti keterbatasan modal, tenaga kerja hingga keterampilan.

Modal sosial adalah salah satu modal yang sangat penting dalam menjaga kelangsungan usaha dalam sektor perdagangan informal. Sebagaimana didefenisikanBourdieu, modal sosial sebagai keseluruhan sumberdaya baik yang aktual maupun potensial yang terkait dengan kepemilikan jaringan hubungan kelembagaan yang tetap dengan didasarkan pada saling kenal dan saling mengakui. Dengan kata lain, dengan menjadi anggota dari suatu kelompok orang akan memperoleh dukungan dari 
modal yang dimiliki secara kolektif. Selanjutnya ia mengatakan bahwa besarnya modal sosial yang dimiliki seorang anggota dari suatu kelompok tergantung pada seberapa jauh kuantitas maupun kualitas jaringan hubungan yang dapat diciptakannya, serta seberapa besar volume modal ekonomi, budaya dan sosial yang dimiliki oleh setiap orang yang ada dalam jaringan hubungannya ${ }^{15}$.

\section{Proses Pengembangan Sektor Perdagangan oleh Pelaku Usaha Kecil Mikro dan Menengah}

Usaha Mikro, Kecil dan Menengah (UMKM) memainkan peran penting di dalam pembangunan dan pertumbuhan ekonomi, tidak hanya di negara-negara sedang berkembang (NSB), tetapi juga di negara-negara maju (NM). Di negara maju, UMKM sangat penting, tidak hanya kelompok usaha tersebut menyerap paling banyak tenaga kerja dibandingkan usaha besar (UB), seperti halnya di negara sedang berkembang, tetapi juga kontribusinya terhadap pembentukan atau pertumbuhan produk domestik bruto (PDB) paling besar dibandingkan kontribusi dari usaha besar ${ }^{16}$.

UMKM adalah unit usaha produktif yang berdiri sendiri, yang dilakukan oleh orang perorangan atau badan usaha di semua sektor ekonomi. Pada prinsipnya, pembedaan antara Usaha Mikro (UMI), Usaha Kecil (UK), Usaha Menengah (UM), dan Usaha Besar (UB) umumnya didasarkan pada nilai aset awal (tidak termasuk tanah dan bangunan), omset rata-rata per tahun, atau jumlah pekerja tetap. Namun definisi UMKM berdasarkan tiga alat ukur ini berbeda menurut negara. Karena itu, memang sulit membandingkan pentingnya atau peran UMKM antar negara ${ }^{17}$.

Usaha Mikro adalah usaha produktif milik orang perorangan dan/atau badan usaha perorangan yang memenuhi kriteria Usaha Mikro. Kriteria usaha mikro adalah memiliki kekayaan bersih paling banyak Rp50.000.000,- tidak termasuk tanah dan bangunan tempat usaha; atau memiliki hasil penjualan tahunan paling banyak Rp300.000.000,- Usaha Kecil memiliki kekayaan bersih lebih dari Rp50.000.000,- $\leq$ Rp500.000.000,- tidak termasuk tanah dan bangunan tempat usaha; atau memiliki

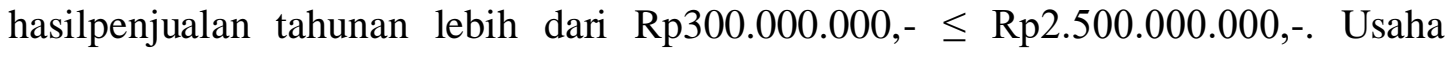
Menengah jumlah kekayaan bersih lebih dari Rp500.000.000,- $\leq$ Rp10.000.000.000,- 
tidak termasuk tanah dan bangunan tempat usaha; atau memiliki hasil penjualan tahunan lebih dari Rp 2.500.000.000,- $\leq$ Rp50.000.000.000,- (lima puluh milyar rupiah) (UU no 20 Tahun 2008).

Modal sosial yang dimiliki individu maupun kelompok memberikan manfaat terhadap individu maupun anggota kelompok dalam mencapai tujuan. Terbentuknya kelompok Asosiasi Kelompok Usaha Rakyat Indonesia (AKURINDO) di Tapanuli Utara yang merupakan wadah UMKM. Para pelaku UMKM di wadah Kegiatan AKURINDO diperlengkapi dengan pemberdayaan anggota melalui pelatihan, pendampingan, akses modal, dan akses pasar. Setiap tahun, anggota diikutsertakan dalam pameran yang diselenggarakan di berbagai tempat.AKURINDO menciptakan dorongan dalam meluasnya sebuah jaringan sosial yang membuat setiap orang saling berhubungan sedemikian rupa sehingga membentuk kepercayaan satu sama lain. Sebagaaimana padangan Field, seseorang akan berhubungan melalui serangkaian jaringan dan mereka cenderung memiliki kesamaan nilai dengan anggota lainnya dalam jaringan tersebut, sejauh jaringan tersebut menjadi sumber daya maka hal tersebut dapat dipandang sebagai modal sosial ${ }^{18}$.

Terdapat pula kelompok-kelompok UMKM informal yang tidak terlalu mengikat. Kewajiban dan harapan yang timbul dari rasa kepercayaan dalam lingkungan sosial yang terdapat pada kelompok-kelompok UMKM mendorong mereka untuk membentuk arisan. Arisan terbentuk karena beberapa kesamaan seperti kesamaan produk usaha, kesamaan daerah asal, kesamaan suku, hubungan kerabat dan rasa kepercayaan yang telah dimiliki satu sama lain. Hal ini mendorong informasi menyebarluas sehinngga membentuk jaringan sosial.

\section{Pembentukan Modal Sosial Pada Usaha Mikro Kecil dan Menengah}

\section{a. Keluarga}

Usaha Mikro Kecil dan Menengah yang berkembang di Tapanuli Utara dapat disebut sebagai usaha keluarga. Pada awalnya usaha mikro kecil dan menengah sudah cukup dikerjakan oleh anggota keluarga. Pemilik usaha mempekerjakan saudara sendiri karena lebih mempercayaikeluarga sendiri dari pada mempekerjakan orang lain. 
117 AT-TAWASSUTH: Jurnal Ekonomi Islam, Volume VI No. 1

Januari - Juni 2021: 107 - 131

Dengan melihat pada dasar pembentukan modal sosial yang masih mendasarkan pada aspek kekeluargaan maka jenis modal sosial yang terjadi adalah modal sosial bonding (bersifat mengikat). Sifat-sifat dalam budaya tersebut yang mengikat para pelaku usaha yang bergerak pada usaha mikro kecil dan menegah di Tapanuli Utara antara satu dengan yang lain untuk saling bekerjasama dan saling membantu.

\section{b. Markombur dan Marnonang}

Markombur dan marnonang telah menjadi kebiasaan bahkan membudaya di masyarakat Batak Toba.Markombur merujuk kepada kegiatan diskusi dalam rangka menghabiskan waktu luang tanpa mempertimbangkan esensi ataupun manfaat dari topik yang dibahas. Sedangkan marnonang bukan bertujuan untuk menghabiskan waktu luang melainkan untuk mengisi waktu luang dengan hal-hal yang memberi pencerahan. Kegiatan makombur dan marnonangdilaksanakan di lapo (kedai tuak atau kedai kopi), waktu pelaksanaannya umumnya pada sore hingga malam hari setelah orang pulang dari tempat bekerja seperti dari sawah atau kantor. Markombur dan marnonang dilaksanakan dalam suasana informal yang rileks dan santai, menimbulkan canda tawa sehingga orang yang terlibat merasa tidak bosan. Topik yang didiskusikan bermacam-macam, seperti hal-hal yang berkaitan dengan kehidupan sehari-hari hingga kehidupan mendatang.

Markomburdan marnonang merupakan salah satu bentuk kegiatan bersama dengan modal sosial yang tinggi. Kebiasaan markombur dan marnonang menimbulkan sebuah transfer ilmupengetahuan dari satu orang ke orang yang lain. Apabila pengusaha yang satu kekurangan tenaga, dapat dibantu oleh orang yang lain, atau ketika permintaan hasil produksi usaha semakin tinggi maka mereka yang semula hanya diminta membantu dengan upah borongan sesuai dengan hasil perolehan produk yang dikerjakan tersebut kemudian mulai mendirikan usaha-usaha baru. Modal sosial dalam bentuk kepercayaan, jaringan usaha, kebersamaan dan kepedulian telah tumbuh dalam bentuk kegiatan tersebut.

\section{c. Kumpulan Sosial dan Keagamaan}


Kegiatan sosial yang sering dilaksanakan adalah partangiangan (ibadah) dan arisan perkumpulan marga. Sedangkan kegiatan keagamaan yang paling banyak dilaksanakan adalah kegiatan kumpulan paduan suara (koor) dan kebaktian lingkungan Gereja. Banyaknya kegiatan sosial dan keagamaan yang ada pada masyarakat di Tapanuli Utara membuat intensitas pertemuan mereka menjadi tinggi. Ketika hari minggutiba, pada pagi hari mereka bertemu di Gereja untuk melaksanakan ibadah bersama, sedangkan pada sore hari mereka bertemu di rumah salah seorang anggota perkumpulan marga untuk melaksanakan partangiangan dan arisan. Sosial dan keagamaan masyarakat di Tapanuli Utara sangat kuat, hal ini berdampak pada kegiatan bersamaan yang menjunjung tinggi norma-norma sosial dan agama. Bekerja tidak hanya untuk mendapatkan penghidupan, tetapi juga sebagai cara untuk bersosial dan beribadah.

\section{d. Pelatihan Informal}

Pelatihan informal adalah pelatihan yang diberikan pengusaha kepada anggotanya yang baru bergabung pada unit usahanya di Tapanuli Utara. Pelatihan dilakukan sendiri oleh pengusaha, karena mereka rata-rata tidak memiliki banyak anggota. Mereka hanya memiliki satu sampai dengan dua orang anggota dan dibantu isteri atau anakpengusaha tersebut. Hal ini dilakukan untuk menghemat penggajian anggota. Pelatihan anggota diawali dengan pemberian tugas langsung, tanpa diawali oleh teori. Anggota yang baru mengerjakan pekerjaan dengan tingkat kesulitan yang rendah, seperti membelanjakan bahan-bahan yang akandiproduksi, kemudian mengolah bahan tersebut sesuai dengan contoh cetakan yang telah ada.

\section{e. Pelatihan Formal}

Pelatihan formal dilakukan oleh instansi resmi yang dibina oleh pemerintah daerah, seperti Koperasi dan Balai Latihan Kerja (BLK). Koperasi sangat berpean penting sebagai wadah untuk membangun modal sosial dalam bentuk kerjasama dan kepercayaan. Jalinan kerja sama yang telah terbentuk karena faktor sosial dan budaya menjadi lebih kuat dengan adanya koperasi. Dengan adanya koperasi maka mulai terjadi perubahan dalam masyarakat, keberadaan kerja sama lebih didasarkan pada kepentingan ekonomi dan bukan lagi karena sosial dan budaya. Di masyarakat kini sedang berkembang Koperasi Kredit atau Credit Union (CU), yang merupakan 
119 AT-TAWASSUTH: Jurnal Ekonomi Islam, Volume VI No. 1

Januari - Juni 2021: 107 - 131

lembaga keuangan yang bergerak di bidang simpan pinjam yang dimiliki dan dikelola oleh anggotanya dan yang bertujuan untuk mensejahterakan anggotanya sendiri.

Dalam rangka menumbuh kembangkan usaha mikro kecil dan menengah di Tapanuli Utara, pemerintah membangun Balai Latihan Kerja (BLK). Balai Latihan Kerja Tapanuli Utara yang berlokasi di Silangkitang, KecamatanSipoholon menjadi pusat sumber daya manusia dengan berbagai keahlian seperti otomotif, bangunan, listrik, pertanian, menjahit, kecantikan dan bidanglainnya.

\section{Peran Modal Sosial Pada Pelaku Usaha Mikro Kecil dan Menengah}

Putnammengungkapkan bahwa modal sosial merupakan corak kehidupan sosial yang terdiri dari jaringan, norma, dan kepercayaan yang membuat parapartisipan sanggup untuk bertindak efektif secara bersama-sama untuk mencapai tujuan bersama. Modal sosial merupakan konsep yang muncul sebagai hasil dari interaksi masyarakat dalam jangka waktu yang lama dan terus-menerus. Interaksi, komunikasi, dan kerja sama yang ada dipengaruhi keinginan untuk mencapai tujuan bersama yang terkadang berbeda dengan tujuan diri sendiri. Hal ini akan menciptakan ikatan emosional untuk menyatukan masyarakat sehingga menghasilkan kepercayaan dari relasi yang lama ${ }^{19}$.

\section{a. Jaringan}

Modal sosial dengan memberikan penekanan pada jejaring sosial (socialnetworks) yang memberikan akses terhadap sumber-sumber daya kelompok yang pada akhirnya akan menikmatimanfaat ekonomis. Stok sub dimensi jejaring tinggi pada wilayah dengan sistem kemasyarakatan yang terpeliharadengan baik secara terus menerus, sebaliknya egoisme dan sikap individualis akan menyebabkan stok sub dimensi ini rendah ${ }^{20}$.

Jaringan pada usaha mikro kecil dan menengah di Tapanuli Utara terdiri dari jaringan formal dan informal. Jaringan informal yang berkembang pada usaha mikro kecil dan menegah di Tapanuli Utara adalah jaringan kekerabatan. Sementara itu, dasar dari pembentukan jaringan sosial di antara mereka adalah adanya keakraban, solidaritas, integrasi dan kepercayaan yang ada di antara mereka yang terbentuk melalui interaksi sosial di antara mereka. Dimana usaha yang ada di sentra ini diwarisakan turun temurun oleh keluarga mereka. Jaringan kekerabatan dimanfaatkan pengusaha dan sebagai metode penyerapan tenaga kerja, proses produksi, distribusi 
produk, bahkanhingga konsumsi produk.Pengusaha mendapat tenaga dari kerabat mereka atau orang yang telah dikenal dekat, terutama apabila anggota keluarga membutuhkan pekerjaan. Hal ini dipengaruhi oleh ikatan kekerabatan yang menghasilkan ikatan yang kuat antara pengusaha dengan anggotanya yang berasal dari keluarganya sendiri.

Jaringan di antara pelaku usaha mikro kecil dan menengah di Tapanuli Utara ditandai dengan keakraban dan prinsip saling tolong menolong. Jaringan yang terbentuk pada usaha mikro, kecil dan menegah di Tapanuli Utara ditujukan untuk kerja sama ekonomi yang menguntungkan semua pihak yang menjadi anggotanya. Untuk memperkuat kerja samadi antara mereka maka dibentuklah suatu koperasiyang mewadahi kerjasama tersebut. Jaringan yang dimiliki koperasi selain bertujuan untuk simpan pinjam yang membantu permodalan hingga berupa pemasaran produk yang dihasilkan keluar daerah yang dapat menembus pasar besar.

\section{b. Kepercayaan}

Kepercayaan (trust) memiliki kontribusi yang cukup tinggi dibandingkan sub dimensi dari modal sosial yang lain. Hal ini menjelaskanalasan dari Fukuyama (1995) yang menggunakan konsep kepercayaan untuk mengukur tingkat modal sosial $^{21}$.Kepercayaan datang dari pengusaha, sebagai pimpinan dalam usaha mikro kecil dan mengeha, atau sebaliknya kepercayaan anggota terhadap pimpinannya. Bentuk kepercayaan tersebut terlihat saat pemilik usaha meminta pendapat kepada anggotanya dalam proses pemilihan bahan baku, produksi produk, distribusi produk sampai dengan pemasaran hasil usaha. Pengusaha melibatkan anggota dalam proses itu agar anggota merasa diberikan kepercayaan dari pengusaha untuk mengutarakan pendapatnya. Hal ini juga meringankan beban pengusaha dalam mengambil keputusan karena telah membagi tugaskepada anggotanya.

\section{c. Norma}

Jati diri modal sosial yang sebenarnya adalah nilai-nilai dan normayang dipedomani sebagai acuan bersikap, bertindak dan bertingkah laku, serta berhubungan dengan pihak lainyang mengikat kepada proses perubahan dan upaya masyarakat yang untuk mencapai suatu tujuan. Nilai danunsur tersebut terwujud dalam sikap partisipatif, sikap saling memperhatikan, saling memberi dan menerima,saling percaya, kemauan 
masyarakat atau kelompok tersebut untuk secara terus-menerus proaktif baik dalammempertahankan nilai, membentuk jaringan-jaringan kerja sama maupun dengan penciptaan kreasi dan ide-ide baru, yang keseluruhannya diperkuat oleh nilai-nilai dan norma yang mendukungnya ${ }^{22}$.

Norma yang dianut dan berjalan pada usaha mikro kecil dan menegahantara pengusaha dengan anggota serta dengan pihak lain bersifat lisan. Norma dapat berupa pembagian kerja, toleransi waktu kerja. Karena cenderung tidak memiliki jam kerja, toleransi dalam jam masuk bekerja berlaku. Norma lain yang ada pada usaha mikro kecil dan menegah adalah pengawasan kualitas produk. Saat pengusaha tidak dapat mengawasi pekerjaan anggotanya yang berkaitan kualitas produk, anggota senior yang merupakan kepercayaan pengusaha, mengontrol, mengarahkan dan membimbing pekerjaan anggota lainya. Norma berikutnya yang berlaku adalah norma kesopanan. Hal yang prinsipil adalah pengusaha dan anggota saling menghargai dan menghormati dalam bertindak. Pengusaha menerapkan norma kesopanan untuk meminimalisir terjadinya konflik antar anggota maupun anggota dengan dirinya sebagai pemilik usaha.

\section{d. Kemimpinan}

Dalam mengelola agar anggota dapat menyelesaikan hasil produksi usaha mikro kecil dan menengah dengan baik dan tepat waktu. Anggota yang bekerja harus sudah paham dan bertanggung jawab dengan tugas mereka masing-masing walaupun tidak pernah ada job description. Jarang ditemui masalah yang tidak bisa diselesaikan sehingga dapat menghambat kinerja, karena pengusaha berupaya memberikan hak mereka dan memberikan motivasi yang lebih agar mereka mampu mandiri dikemudian hari. Dari hasil penelitian dapat dilihat peran seorang pengusaha usaha mikro kecil dan menegah di Tapanuli Utara sangat berpengaruh terhadap peningkatan kinerja pegawai dan efektifitas kerja pegawai. Kepemimpinan pengusaha dapat dilihat dengan ketegasan yang dibuat pemilik usaha dalam mengontrol kegiatan ekonomi yang dikerjakan.

\section{e. Solidaritas}


Rasa solidaritas menyangkut hubungan antara pengusaha dengan sesama pengusaha dan juga dengan anggotanya. Solidaritas dalam usaha kecil mikro dan menengah di Tapanuli Utara sangat tinggi. Pelaku usaha sudah memahami rasa persatuan dan kebersamaan dengan salingmenguntungkan. Pelaku usaha memanfaatkan kedekatan hubungan kekerabatan dan pertemanan untuk membangun solidaritas. Hubungan kekerabatan, rasa memiliki, rasa kesetiaan atau loyalitas yang sangat tinggi, sifat rajin, dan hasrat bekerja keras ditanamkan pemilik usaha kepada anggotanya. Ini dilakukan dengan membangun kedekatan secara emosional dengan anggotanya. Anggota diperlakukan sebagai seorang keluarga, karena mereka seharihari bersama dengan pengusaha, berkomunikasi secara rutin dan berkelanjutan. Hal ini menimbulkan rasa kebersamaan dan solidaritas yang tinggi dalam usaha mikro kecil dan menengah, menciptakan suasana satu tim kerja yang solider sebagai satu tim kerja. Pengusaha dan anggotanya melakukan pendekatan dalam pekerjaan dengan membuat keputusan-keputusan yang akan membawa kesatuan tujuan bersama. Kesatuan tujuan inilah yang membawa kerja sama yang baik demi mencapai keberhasilan usaha.

\section{Manfaat Modal Sosial Pada Usaha Mikro Kecil dan Menegah}

\section{a. Gotong Royong}

Budaya gotong royong membuka jalan terjadinya transfer pengetahuan kepada orang lain yang merupakan tetangga dan kerabat yang pada awalnya hanya membantu pekerjaan pada usaha mikro kecil dan menengah. Ketika permintaan produk usaha meningkat, maka mereka yang semula hanya membantu secara gotong-royong dengan imbalan ala kadarnya dari para pemilik usaha, mulai mendirikan usaha mikro kecil dan menengah yang baru. Walaupun gotong royong pada usaha mikro kecil dan menegah di Tapanuli Utarasudah mulai bergeser ke kepentingan ekonomi, namun tidak melupakan konsep dasarnya. Gotong royong dilakukan dengan menawarkan bantuan kepada tetangga yang sedang mendapatkan banyak pesanan. Pemilik usaha juga kerap menawarkan pekerjaan yang tidak dapat mereka cukupi kepada rekan pengusaha lain yang sedang sepi pesanan dengan kualitas pekerjaan yang dipantau oleh pemilik pesanan. Kondisi saling menguntungkan ini menjadikan hubungan kekerabatan yang semakin kuat.

\section{b. Transfer Ilmu}


Salah satu cara yang dilakukan untuk transfer ilmu adalah dengan mensosialisasikan model barang yang dipesan konsumen. Pengusaha menjelaskan kepada anggotanya spesifikasi barang produksi yang diinginkan pemesan. Transfer ilmu juga tejadi pada proses pelatihan anggota baru. Pada dasarnya, anggota baru telah mengetahui dasar-dasar pembuatan barang produksi, karena anggota baru ini pada umumnya berasal dari tetangga atau kerabat pengusaha yang tinggal tidak jauh dari sentra perdagangan usaha kecil mikro dan menengah. Transfer ilmu menjadi semakin efektif saat anggota telah mampu menyesuaikan diri dengan lingkungan baru dimana dia bekerja.

Transfer ilmu dapat dilihatpula pada produk industri rumah tangga seperti kerajinan tenun tradisional. Para penenun senior yang telah mahir bertenun seringkali mengajarkan cara bertenun serta model ataupun design tenun kepada para penenun yang baru belajar. Penenun baru sering bertama ke rumah penenun senior untuk belajar dan sering pula para penenun baru menunjukkan model-model tenunan yang sedang naik daun saat ini. Pada kesempatan yang sama para penenun juga sering berbagai pengalaman tentang pemasaran produk yang saat ini dilakukan dengan media sosial.

\section{c. Komunikasi}

Metode komunikasi yang paling sering digunakan pengusaha untuk menyampaikan pesan kepada anggotanya adalah dengan pesan lisan, sementara untuk metode tulisan dan gambar masih jarang digunakan.Metode tulisan dan gambar biasanya digunakan saat mereka memodifikasi sebuah hasil produksi, hal ini juga jarang dilakukan. Mengingat budaya tulisan yang memang tidak menjadi budaya akar dari pelaku usaha. Pengusaha lebih senang menggunakan perintah lisan, lebih mudah disampaikan dan mereka juga menganggap anggota paham dengan apa yang disampaikannya.

\section{Bentuk-Bentuk Modal Sosial Yang Dilakukan Pelaku Usaha Mikro Kecil dan Menengah}

Dalam sektor perdagangan modal sosial merupakan hal penting yang dimanfaatkan pedagang untuk dapatmeningkatkan aktivitas perdagangannya serta 
mendapatkan keuntungan yang besar. Hanya saja modal sosial yang dilakukan setiap pengusaha atau kelompokpelaku usaha berbeda satu dengan yang lain. Hal ini yang menciptakan bentuk-bentuk modal sosial dikalangan pengusaha usaha mikro kecil dan menengah.

\section{a. Kas Bon Sebagai Bentuk Rasa Saling Percaya Kepada Distributor dan Pelanggan Sektor Perdagangan}

Kas bon atau yang juga biasa dikenal dengan hutang merupakan suatu tindakan yang dapat ditemui dalam kegiatan perdagangan. Kas bon biasanya diberikan oleh distributor atau pemasok barang kepada pedagang. Kas bon merupakan bentuk rasa saling percaya karena distributor mengizinkan pedagang mengambil barang terlebih dahulu sedangkan pembayaran dilakukan setelah barang diterima, bahkan ada yang pembayarannya dapat dilakukan setelah barang terjual. Kegiatan tersebut hanya dapat dilakukan jika sudah terbangun rasa saling percaya. Kas bon juga diberikan pedagang kepada pelanggan. Pedagang akan memberikan kas bon atau hutang kepada pembeli yang sudah tergolong pelanggan. Hal itu dikarenakan sudah munculnya rasa saling percaya di antara kedua belah pihak.

\section{b. Menitipkan Toko Ke Pedagang Lain Sebagai Wujud Rasa Saling Percaya Sesama Pegusaha}

Menitipkan toko ke pedagang lain sering terjadi pada sektor perdagangan. Bagi pengusaha, sesama pedagang merupakan orang yang dapat dipercaya. Ketika suatu waktu pengusaha harus pergi dalam waktu yang tidak lama, mereka tidak harus menutup toko, namun dapat menitipkan toko ke pedagang sebelah. Kondisi ini hanya dapat dilakukan apabila telah terbangun rasa saling percaya. Pengusaha juga lebih percaya kepada kerabatnya sehingga ketika ingin meninggalkan toko, maka yang dilakukan adalah menghubungi saudaranya yang berjaga di toko lain untuk datang dan menjaga tokonya.

\section{c. Jaringan Kekerabatan (Tondong), Teman Sekampung Halaman (Dongan Sahuta) dan Pertemanan (Ale-ale)}

Pengusaha lebih dominan mempekerjakan orang yang telah dikenal seperti kerabat, teman sekampung dan teman dekat yang secara umum disebut saudara. Hal tersebut dikarenakan pengusaha lebih percaya dengan orang yang dikenal daripada 
125 AT-TAWASSUTH: Jurnal Ekonomi Islam, Volume VI No. 1

Januari - Juni 2021: 107 - 131

orang lain. Keinginan untuk menolong orang yang dikenal terlebih dahulu juga menjadi faktor pendorong, dengan memberikan pekerjaan dalam usaha perdaganganya. Saudara yang bekerja tidak dianggap sebagai pegawai melainkan rekan kerja sehingga jarak antara pemilik perdagangan dengan pekerja tidak terlalu jauh. Hampir seluruh pengusaha yang ditemui mengatakan bahwa anggotanya masih merupakan saudara. Pengusaha menganggap apabila masih ada saudara yang dapat membantu mengapa harus mengharapkan orang lain. Sebagai pengusaha juga beranggapan dengan memperkerjakan saudara dapatmenghemat biaya gaji, dibandingkanmempekerjakan orang lain yang pasti mengeluarkan biaya yang besar. Hal ini dikarenakan sektor perdagangan pada usaha mikro kecil dan menengah relatif tidak mendapatkan keuntungan yang besar.

Saudara digunakan untuk mempermudah usaha perdagangan yang dilakukan. Saudara menjadi pemeran utama dalam praktek kerja usaha perdagangan. Banyak dijumpai kegiatan perdagangan yang dilakukan selalu bekerja sama dengan perdagangan yang dimiliki saudara. Pengusaha membuka perdagangan sejenis di tempat yang sama dengan keluarganya yang lain dan pelaksanaannya dilakukan dengan saling bekerja sama. Hal tersebut memberikan keuntungan secara material kepada menguntungkan masing-masing pihak, karena dalam proses pemasokan barang mendapatkan banyak kemudahan, dimana barang yang dibeli dalam jumlah yang banyak mendapatkan potongan harga yang besar bonus lainnya.

Jaringan kekerabatan, teman sekampung dan pertemanan dimanfaatkan pengusaha dalam pemasaran produk yang diperdagangkan. Aktivitas pemasaran produk tidak hanya dilakukan dari toko, seringkali pedagang langsung turun kelapangan dengan langsung berjualan ke rumah-rumah penduduk. Pedagang yang berjualan membawa barang yang diperdagangkan dengan menggunakan beko/gerobak sorong, sepeda motor dan mobil pick up. Pedagangmenjajakan barang dagangannya ke daerah-daerah di mana kerabat, teman sekampung dan temannya tinggal, dengan demikian barang dagangannya dapat cepat terjual dan secara tidak langsung kerabat, teman sekampung dan temannya dapatmempromosikan barang tersebut kepada tetangga/masyarakat di daerah tersebut. Apabila di suatu daerah tidak 
ada kerabat, teman sekampung danteman pedagang yang dikenal, pedagang tersebut akan menarik hubungan kekerabatan melalui hubungan marga kepada penduduk daerah tersebut. Strategi ini dianggap ampuh untuk meningkatkan hasil perdagangan.

\section{d. Jaringan Pengusaha dengan Anggota Memunculkan Patron Klien}

Pengusaha selalu menjaga hubungan yang harmonis dengan anggotanya. Pengusaha seringmemberikan bonus atau tambahan uang kepada pekerjanya.Tidak jarang pengusaha membelikan makanan, menambah gaji,hingga mengajak berlibur bersama. Pekerjaan yang diterima pekerja cukup berat dan seringkali tidak ada waktu untukberlibur, pada saat adawaktu luang, pengusahasering membuat candaan, suasana ini membuat pekerja merasa betah dan menganggap atasannya pribadi yang baik. Kebaikan-kebaikan seperti ituyang menimbulkan rasa patron klien. Pekerja merasa berhutang budi atas kebaikan-kebaikan tersebut dan merasa tidak enakkan jika harus keluar dari pekerjaannya.

\section{e. Keikhlasan Sesama Pengusaha}

Keikhlasan sesama pedagang terlihat pada tindakan saling tukar. Apabila seorang pembeli ingin mencari suatu barang namun barang tersebut tidak dimiliki pedagang, pedagang merekomendasikan pembeli ke toko pedagang lain, begitu pula sebaliknya. Beberapa pedagang menunjukkan toko saudaranya yang lebih dekat terlebih dahulu apabila barang yang dicari pembeli kosong di tokonya. Keuntungan tindakan keikhlasan saling tolong menolong sesama pedagang memang tidak langsung dirasakan pada saat itu juga, namun merupakan tindakan resiprositas yang sudah dibangun antar pedagang.

\section{f. Norma Untung Rugi Menjadi Tentatif PadaPedagang}

Norma untung rugi menjadi norma utama karena apapun yang terjadi dalam dunia perdagangan, untung rugi menjadi pertimbangan pertama. Sebisa mungkin keuntungan sebesar-besarnya didapat. Pengusaha terus berupaya mempertahankan dan meningkatkan pelanggannya. Segala macam usaha dilakukan untuk menarik dengan menaikkan minat pembeli untuk berbelanja.

Sedangkan bagi sebagian pengusaha norma untung rugi juga dipertimbangkan, namun tidak menjadikan keuntungan yang sebesar-besarnya sebagai tujuan utama yang harus didapat dengan berbagai cara. Keuntungan yang 
127 AT-TAWASSUTH: Jurnal Ekonomi Islam, Volume VI No. 1

Januari - Juni 2021: 107 - 131

diperoleh lebih kepada kepuasan pelanggan, walaupun sering ditemui pedagang mendapatkan untung yang sangat kecil bahkan balik modal. Sebagian pengusaha lebih memaknai perluasan jaringan sosial dan etos kerja seperti semangat kerja, kesopanan serta kejujuran sebagai sebuah keuntungan.

\section{g. Semangat Kerja Sebagai Nilai-nilai Yang Dipegang Pengusaha}

Pada pasar tadisional yang menjadi lokasi penelitian, toko yang dimiliki pedagang buka tepat waktu. Bahkan untuk hari-hari besar tertentu, pedagang tidak menutup tokonya dalam arti perdagangan mereka tetap beroperasi. Seperti pada hari raya idul fitri, natal dan tahun baru. Pedagang tetap membuka tokonya, hanya hari besar natal dantahun baru saja tutup dalam setahun. Hal tersebut menunjukkan semangat kerja yang tertanam dalam yang cukup besar dalam dunia perdagangan.

Semangat kerjapedagang di Tapanuli Utara tergolong sangat besar, dimana sebagain besar pedagang memulai usaha sebelum matahari terbit. Pedagang menganggap semakin cepat memulai perdagangan maka semakin banyak rezeki yang akan datang. Usaha perdagangan yang mereka lakukan berupa hasil produksi pertanian, seperti menjual sayur mayur, bawang, cabai dan lain sebagainya. Usaha perdagangan tersebut jauh lebih baik dimulai pagi hari, karena pembeli cenderung berbelanja pagi hari untuk kebutuhan rumah tangga. Semangat pedagang sangat besar walaupun keuntungan yang diperoleh dari penjualan hasil pertanian tidak terlalu besar, bahkan berpeluang rugikarena apabilatidak laku dijual,barang dagangan tersebut cepat layu dan busuk.

\section{h. Ramah, Sopan, dan Hemat Menjadi Nilai-Nilai yang Dipegang Pedagang}

Ramah, sopan, dan hemat menjadi modal penting dalam menerapkan nilainilai dalam berdagang. Tutur kata yang santun dari pedagang membuat pembeli merasa nyaman jika berbelanja. Nilai hemat juga dipegang oleh pedagang, dapat dilihatdari lokasi berjualan sebagian besar toko dengan ukuran kecil dan sedang. Ukuran toko sangat mempengaruhi biaya sewa, semakin besar ukuran toko, semakin besar pula pembayaran sewa setiap bulannya. Penerapan nilai hemat ini ternyata berdampak postif juga terhadap perdagangan mereka. Setiap bulan uang sewa yang 
dibayarkan tidak terlalu besar namun tetap mendapat keuntungan dari penjualan atas barang yang dijual.

\section{i. Kemandirian Menjadi Nilai Dasar Perdagangan}

Bagi sebagian pengusaha berdagang telah menjadi profesi yang sudah sejak turun temurun mereka geluti. Dimana mereka tinggal melanjutkan usaha perdagangan milik orang tuanya. Namun banyak pula pedagang yang benar-benar secara mandiri memulai usaha perdagangan hanya dengan bermodalkan keahlian yang telah diajarkan keluarganya dalam berdagang atau diperoleh dari pengalaman di lapangan.

Nilai kemandirian bagi pengusaha yaitu merintis usaha sendiri walau berawal sangat sederhana dan dengan modal yang tidak terlalu besar. Kemandirian tersebut terlihat dari tidak memakainya jasa anggota yang akan membantu mereka. Banyak pedagang tidak memiliki bawahan atau anggota. Apabila membutuhkan tenaga dalam pekerjaan, mereka akan meminta bantuan dari keluarga sendiri tanpa harus mencari orang lain.

\section{j. Kerapihan, Kreatifitas, dan Inovatif Pedagang}

Kerapihan, kreatifitas dan inovatif menjadi nilai pendukung dari perdagangan. Kerapihan tersebut terlihat dari susunan dan tata letak barang dagangan yang mereka susun. Bagi pedagang kerapihan menjadi hal penting dalam menarik pembeli. Pembeli akan melihat kerapihan terlebih dahulu sebelum mempertimbangkan hal lain, sehingga pedagang sangat menjaga kerapihan tokonya.

Kreatifitas dan inovatif juga menjadi hal penting lainnya. Mungkin saja jika tidak adanya kreatifitas dan inovatif akan membuat pembeli merasa jenuh dan bosan dengan barang dagangan yang begitu-begitu saja. Alasan itu yang membuat pedagang akan terus berupaya mencari kreatifitas yang terus berganti dan menemukan inovasi baru, baik dari segi bentuk maupun ragam dagangannya.

\section{Kesimpulan}

Krisis perekonomian nasionalyang terjadisaat ini sangat mempengaruhi stabilitas nasional,yang berdampak pada berbagai kegiatan usaha besar yang semakinterpuruk. Kehadiran usaha mikro, kecil dan menengah dalam sektor perdagangan dapat menjaga stabilitas perekonomian terutama dalam memperkuat struktur perekonomian nasional.Diperlukan pemanfaatan modal sosial dalam sektor 
129 AT-TAWASSUTH: Jurnal Ekonomi Islam, Volume VI No. 1

Januari - Juni 2021: 107 - 131

perdagangan untuk menjadikan usaha mikro, kecil dan menengah, mandiri dan tangguh sertamemiliki daya saing yang tinggi, dimana semua pelaku usaha berperan utama dalam kegiatan ekonomi; mulai dari produksi, distribusi dan hingga dikonsumsi.

Proses pengembangan sektor perdagangan oleh pelaku usaha mikro, kecil dan menengah dimulai dari pembentukan modal sosial pada usaha mikro kecil dan menengah. Pembentukan modal sosial berasal dari keluarga, markombur dan marnonang, kegiatan sosial dan keagamaan, pelatihan informal dan pelatihan formal. Terbentuknyamodal sosial tersebut berperan dalammemperluas jaringan, membangun kepercayaan, memeliharanorma, membentuk kepemimpinan dan meningkatkan solidaritas pelaku usaha mikro, kecil dan menengah.Peran tersebut bermuara pada manfaat modal sosial yang berupa peningkatan gotong-royong, transfer ilmu dan komunikasi pada usaha mikro, kecil dan menengah. Manfaat modal sosial tersebut diaktualisasikan dalam bentuk-bentuk modal sosial yang dilakukan pelaku usaha mikro kecil dan menengah.

Pada akhirnya jelas disimpulkan bahwa pemanfaatan modal sosial merupakan solusi dalam pengembangan sektor perdagangan pada usaha mikro kecil dan menengah. Modal sosial hanya dapat dibangun ketika setiap individu belajar dan mempercayai individu lain sehingga mereka membuat komitmen yang dapat dipertanggungjawabkan untuk mengembangkan bentuk-bentuk hubungan yang saling menguntungkan. Inti dari modal sosial terletak pada bagaimana kemampuan masyarakat untuk bekerjasama membangun suatu jaringan guna mencapai tujuan bersama.

\section{Endnote}

1 Catur SugiyantoAnalisis Indikator Ekonomi.(PSEKP UGM, Yogyakarta, 2010), hlm. 1.

${ }^{2}$ Arsyad Lincolin. Ekonomi Pembangunan Edisi 5. (UPP STIM YKPN: Yogyakarta, 2010), hlm. 489.

${ }^{3}$ Douglass North.Institutions, Institutional Change, and Economic Performance. (New York, Cambridge University Press, 1990), hlm. 3.

${ }^{4}$ Putnam, Robert D. 1993. "The Prosperous Community Social Capital and Public Life." (The American Prospect, Vol.13, pp. 35-42), hlm. 38. 
Harisan Boni Firmando : Pemanfaatan Modal Sosial ... 130

${ }^{5}$ Nyoman Utari. Modal Sosial dan Pembangunan Wilayah. (Bali. UB Press, 2011), hlm. 14.

${ }^{6}$ Francis Fukuyama. Trust; Kebijakan Sosial dan Penciptaan Kemakmuran. (Yogyakarta: Penerbit Qalam, 2002), hlm. 22.

7James S Coleman. Social Capital In The Creation Of Human Capital (American Journal of Sociology 94: S95-S120, 1988), hlm. 370.

${ }^{8}$ Francis Fukuyama. Trust: The Social Capital and the Creation of Prosperity. New York: Free Press, 1995), hlm. 27.

${ }^{9}$ Bagong Suyantodan Sutinah. Metode Penelitian Sosial: Berbagai Alternatif Pendekatan. (Jakarta: Kencana, 2001), hlm. 166.

${ }^{10}$ Hadari Nawawi. Metode Penelitian Bidang Sosial. (Yogyakarta: Universitas Gadjah Mada Press, 1990), hlm. 203.

${ }^{11}$ Danandjaja. Metode Penelitian Sosial. (Medan: Universitas Sumatera Utara Press, 2005), hlm. 30.

${ }^{12}$ Amri Amir.Analisis Pertumbuhan Ekonomi, Investasi, dan Inflasi di Indonesia. (Jurnal Kajian Ekonomi,Vol. 1, No. 02 Januari 2013), hlm. 15.

${ }^{13}$ Sadono Sukirno, Ekonomi Pembangunan, Proses, Masalah dan Dasar Kebijaksanaan. (Jakarta : UI , LPFE,1985), hlm. 273.

14 Todaro Michael.Pembangunan Ekonomi Di Dunia Ketiga. (Jakarta : Ghalia Indonesia, 2000), hlm. 322.

15 Pierre Bourdieu. "The Forms of Capital”, dalam J. Richardson, ed. Handbook of Theory and Research for the Sociology of Education. (Westport, CT: Greenwood Press, 1986), hlm. 249.

16 Tulus Tambunan. Usaha Mikro Kecil dan Menengah di Indonesia, (Jakarta: LP3ES, 2012), hlm. 1.

${ }_{17}$ Tulus Tambunan. Usaha Mikro Kecil dan Menengah di Indonesia: Isu-Isu Penting, (Jakarta: LP3ES, 2012), hlm. 11.

${ }^{18}$ John Field. Modal Sosial. (Yogyakarta: Kreasi Wacana, 2010), hlm. 1.

${ }^{19}$ John Field. Modal Sosial. (Medan: Bina Media Perintis, 2005), hlm. 51.

${ }^{20}$ Pierre Bourdieu. The Form of Capital. In J. Richardson (Ed). Handbook of Theory and Research for Sociology of Education. (New York: Greenwood Press, 1986), hlm. 51.

${ }^{21}$ Jousairi Hasbullah. Social Capital: Menuju Keunggulan Budaya Manusia Indonesia. (MR-United Press,Jakarta, 2006), hlm. 82.

22 Jousairi Hasbullah.Social Capital: Menuju Keunggulan Budaya Manusia Indonesia. (MR-United Press,Jakarta, 2006), hlm. 8.

\section{Daftar Pustaka}

Amir, Amri. 2013.Analisis Pertumbuhan Ekonomi, Investasi, dan Inflasi di Indonesia. Jurnal Kajian Ekonomi,Vol. 1, No. 02 Januari 2013.

Bourdieu, Pierre. 1986. The Form of Capital. In J. Richardson (Ed). Handbook of Theory and Research for Sociology of Education. New York: Greenwood Press. 
131 AT-TAWASSUTH: Jurnal Ekonomi Islam, Volume VI No. 1 Januari - Juni 2021: 107 - 131

Coleman, James S. 1988. Social Capital In The Creation Of Human Capital. American Journal of Sociology 94: S95-S120, 1988.

Danandjaja. 2005. Metode Penelitian Sosial. Medan: Universitas Sumatera Utara Press.

Field, John. 2005. Modal Sosial. Medan: Bina Media Perintis.

Field, John. 2010. Modal Sosial. Yogyakarta: Kreasi Wacana.

Fukuyama, Francis. 1995.Trust: The Social Capital and the Creation of Prosperity. New York: Free Press.

Fukuyama, Francis. 2002. Trust; Kebijakan Sosial dan Penciptaan Kemakmuran. Yogyakarta: Penerbit Qalam.

Hasbullah, Jousairi.2006. Social Capital: Menuju Keunggulan Budaya Manusia Indonesia. Jakarta: MR-United Press.

Lincolin, Arsyad. 2010. Ekonomi Pembangunan Edisi 5. Yogyakarta: UPP STIM YKPN.

Nawawi, Hadari. 1990. Metode Penelitian Bidang Sosial. Yogyakarta: Universitas Gadjah Mada Press.

North, Douglass.1990. Institutions, Institutional Change, and Economic Performance. New York: Cambridge University Press.

Michael, Todaro.2000. Pembangunan Ekonomi Di Dunia Ketiga. Jakarta : Ghalia Indonesia.

Robert D, Putnam. 1993. "The Prosperous Community Social Capital and Public Life." The American Prospect, Vol.13, pp. 35-42.

Sugiyanto, Catur.2010. Analisis Indikator Ekonomi. Yogyakarta: PSEKP UGM.

Sukirno, Sadono, 1985. Ekonomi Pembangunan, Proses, Masalah dan Dasar Kebijaksanaan. Jakarta : UI , LPFE.

Suyanto, Bagong dan Sutinah. 2001. Metode Penelitian Sosial: Berbagai Alternatif Pendekatan. Jakarta: Kencana.

Tambunan, Tulus.2012. Usaha Mikro Kecil dan Menengah di Indonesia: Isu-Isu Penting. Jakarta: LP3ES.

Utari, Nyoman. 2011. Modal Sosial dan Pembangunan Wilayah. Bali: UB Press. 